\title{
Life-cycle personal accounts proposal for Social Security: An evaluation of President Bush's proposal
}

\author{
Robert J. Shiller* \\ Cowles Foundation for Research in Economics and International Center for Finance, Yale University, \\ 30 Hillhouse Avenue, New Haven, CT 06520-8281, USA
}

Received 12 July 2005; accepted 21 October 2005

Available online 5 December 2005

\begin{abstract}
The life-cycle portfolio proposal for personal accounts within a Social Security system would have the government undertake the dynamic portfolio allocation program for individuals. This paper evaluates, using U.S. historical data 1871-2004, several versions of conventional life-cycle portfolios. The results show disappointing performance relative to the rhetoric of the promoters of the proposal. Dynamic portfolio theory suggests that the optimal life-cycle portfolio may look very different from the conventional form. Moreover, behavioral finance suggests that the design of a life-cycle portfolio for Social Security should consider the attitudes and habits of individuals and as well as their diversity.

(C) 2005 Society for Policy Modeling. Published by Elsevier Inc. All rights reserved.
\end{abstract}

Keywords: Dynamic portfolio theory; Life-cycle portfolio; Social Security system

Any plan for private accounts as part of a Social Security system has to take account of the life-cycle risk-management problem. The optimal portfolio for any worker ought generally to change as that person ages, and so it has been proposed that private accounts should be designed either to optimize over time for the worker or at least to make it convenient for worker to do so within the choices that are provided.

President George W. Bush outlined, in his State of the Union speech and associated documents ${ }^{1}$ in February 2005, the world's most ambitious version of this proposal for life-cycle accounts within Social Security, and campaigned for succeeding months for his plan. Although it now appears

* Tel.: +1 2034323726 .

E-mail address: robert.shiller@yale.edu.

${ }^{1}$ Office of the Press Secretary, The White House (2005a, 2005b). 
unlikely that his plan will be implemented in the near future, it will certainly be a model for such plans in the United States and other countries in future years.

In this paper, I will outline the important issues for life-cycle portfolios within Social Security. For concreteness, and to highlight associated government budget and political realities, I will put this analysis of the life-cycle proposal in the context of the specific proposal of President Bush.

Much discussion of the attractiveness of the life-cycle portfolio reform for social security appears to rely on assumptions that a life-cycle portfolio will yield very high returns with little or no risk. This paper investigates the possible returns and possible risks associated with a life-cycle personal account option. I use U.S. historical returns 1871-2004 to assess the potential range of future investment outcomes under several versions of a life-cycle personal accounts plan that are suggested by recent discussions and examples. The results suggest that workers would be well advised to stay away from such life-cycle plans. This paper concludes with a discussion of issues for the better design of life-cycle accounts.

\section{How the Bush proposal would work}

Under the present U.S. Social Security system, each working individual must contribute $6.2 \%$ of his or her earnings (up to an earnings ceiling, currently $\$ 90,000$ ) to Social Security, and this is matched by another $6.2 \%$ of earnings that the individual's employer must contribute. Upon retirement, the individual's and employer's contributions for all the years that he or she worked, updated for inflation using a wage index, are fed into a formula that determines the annual Social Security benefit that the individual will receive upon retirement. The present formula is progressive, that is, people with lower earnings get relatively more in benefits per dollar contributed than do people with higher earnings. The formula does not take as inputs any financial variables such as interest rates or stock returns, and so the benefits ultimately received are independent of the performance of financial markets. While Social Security benefits are subject to political risk and risks about changes in the economy, they historically have not exhibited any of the annual volatility associated with investments in financial markets.

The proposed new personal account system would be optional: people can stay in the old system (subject to future changes in that system that Congress might make) or elect to have $4.0 \%$ of their $6.2 \%$ contribution (up to a maximum amount that would be phased out by 2041), diverted into personal accounts. They can then allocate these accounts, according to their tastes, into a portfolio of their choosing, subject to the restriction that it be comprised of a few broadly diversified investment funds of stocks and bonds along the lines of the options currently offered to Federal employees through the Thrift Savings Plan (TSP), and including as well a life-cycle fund option, which the TSP has announced plans for, but which it does not currently offer.

But, according to Bush's plan, the personal account does not come for free. Indeed, there is a much-discussed budget problem that Bush's plan must allow for. A plan that simply allows workers to divert part of their Social Security contribution into a personal portfolio will mean that the government will no longer be able to use this part of current contributions to support the current beneficiaries of Social Security. The government will have to borrow money to make up for the money workers have diverted to the personal accounts. So, in an attempt to preserve balance over an infinite horizon, the Bush plan specifies that when the individual finally retires, an "offset" value, the terminal value of the personal account contributions cumulated at a $3 \%$ real interest rate, will be annuitized (converted into a series of payments for life, analogous to the payments that people make on mortgages) and subtracted from the traditional Social Security benefit. In addition to this reduced traditional benefit due to the offset, the worker will also get 
the lump sum value of the personal account, although he or she would be required to annuitize at least enough of that so that the combined traditional benefit and personal account would be above the poverty line, whenever there is enough in the personal account to make that possible. In effect, the worker has not really "diverted" his or her Social Security contributions into a personal account, but has merely borrowed from the government to invest in a personal account, and must eventually pay the loan back. The offset will eventually help the government deal with the debt it incurred to maintain benefits to retirees.

While the plan is described as a way of "fixing" Social Security, in effect, the new personal accounts are nothing more than a plan to encourage people to buy stocks and bonds on margin that is to borrow money to buy stocks, with the Federal government as the lender offering a 3\% real interest rate on the loan. The computation that is made when a worker retires is the same as one that a brokerage firm would do for customers with margin accounts who elected to put the equity in their margin account into a retirement annuity on the day they retired. In the brokerage business, the "offset" would be called the "debit balance" in the margin account. ${ }^{2}$

Of course, there is nothing morally or practically wrong with buying stocks on margin, despite popular prejudices against the practice. Encouraging people to do this might help many of them diversify their personal portfolios better, taking better advantage of higher expected returns from some more risky investments and offsetting the anti-equity bias that infects the portfolios of most small investors. ${ }^{3}$ Encouraging people to buy securities on margin might also help a broad element of the public learn a lesson in finance, thus furthering Bush's goal of promoting an "ownership society." But, we have to think whether this plan for margin purchases of securities is going to work out well for the representative worker who chooses this option.

\section{The life-cycle portfolio}

Bush's plan is based on the concept that the optimal portfolio for most workers is a "life-cycle portfolio." The managers of the life-cycle accounts would invest more aggressively when the worker is young, and gradually more conservatively as he or she ages, in accordance with the advice of most financial advisors. According to Bush's plan, the life-cycle portfolio would be an option for younger workers and all personal accounts would be "automatically invested in the 'life cycle portfolio' when a worker reaches age 47, unless the worker and his or her spouse specifically opted out by signing a waiver form stating that they are aware of the risks involved." 4 Thus, in a sense the life-cycle portfolio is the centerpiece of the personal account plan.

The life-cycle plans are important to the plan in that they attempt to respond to the complaint that Bush's Social Security plan is too risky, that by encouraging people to achieve higher returns on their Social Security contributions by investing in risky assets, they will run major risks that a market decline will impoverish them in their retirement. A life-cycle plan would involve riskier investments only in the earlier years of the life cycle.

\footnotetext{
${ }^{2}$ In this case, however, the "debit balance" is subtracted from the traditional Social Security benefit, although in net this is equivalent to subtracting the balance from the personal account itself.

3 The best-stated theoretical argument for personal accounts is that they encourage people to diversify their portfolios better, see Geanakoplos, Mitchell and Zeldes (2000) the discussion below in this paper and Shiller (2005c). In contrast, many popular accounts of the advantages of personal accounts neglect to note that higher returns that investments such as stocks appear to offer are really just compensation for the higher risk that these investments entail.

4 Office of the Press Secretary, The White House, Strengthening Social Security for the 21st Century (p. 7).
} 
However, the life-cycle plan may also not live up to its promise of giving workers a return higher than they would have gotten under the original Social Security plan. Any plan that deals with risk by investing more conservatively will tend to lower also the expected return.

\section{Methods and assumptions underlying the analysis}

Here I report a simulation of the returns from such life-cycle personal accounts, using longterm historical data. Long-term historical data are important to look at, lest our results be over influenced by recent years, for which stock market returns have been very high. It is common sense that if we want to assess the returns from a lifetime investing strategy, we should look beyond one or two lifetimes: we need to look at the range of history.

I will use for this purpose a U.S. data set on U.S. stocks, bonds and money market 1871-2005 that I assembled years ago for my book Market Volatility, 1989, and also used in my book Irrational Exuberance, Princeton University Press, 2005. In this paper I will use these data both with and without adjustments to returns to reflect international experience.

\subsection{Historical simulation}

I will use returns on stocks, bonds and the money market, from 1871 to 2004 to devise 91 separate draws of a worker's 44-year experiences in these markets. Earnings by age for a representative worker are taken from the "scaled medium earner" developed by the Social Security actuaries; this earner is meant to reflect the typical employment and earnings pattern with rising real wages through age 51 (when they are $337 \%$ higher than they were at age 21) and then falling off by 64 (when they are $28 \%$ lower than they were at age 51). In all of the simulations the worker is born in 1990, starts participating in the accounts in 2011, and retires in 2055 at age 65. The simulations hold the earnings path constant and only vary the rates of return experienced by this hypothetical worker. It is assumed that the worker places the full $4 \%$ of earnings, into a personal account, the maximum under the Bush plan.

\subsection{Assumptions on assets and rates of return}

These simulations require an appropriate series of historical returns and an assumed portfolio. The Social Security Trustees have assumed that future real returns for stocks will be $6.5 \%$ per annum, for government bonds 3\%. This assumption appears close to long-term historical experience for the U.S., see Table $1 .^{5}$ For the years 1871-2004, the geometric average real return on U.S. stocks was $6.8 \%$, for U.S. government bonds $2.6 \%$. For the more recent subsample of 1950-2004, the returns were broadly similar, higher for stocks, lower for bonds. It might seem, then, that the Social Security actuaries were making reasonable assumptions about future returns.

However, there are important reasons to doubt that the numbers can be trusted as a guide to the next century. We do not know that the successful 20th century will be duplicated in the U.S. in the 21 st century. The U.S. has been a very successful country. It would be a mistake to assume that the U.S. will be so extraordinarily successful in the next century. In fact, the Social Security Trustees

\footnotetext{
5 The reader is reminded that returns are computed as geometric averages of gross returns, which are always lower than the arithmetic averages that are often quoted. See Siegel (2002), Stocks for the Long Run. Also, real (inflation-corrected) returns are lower than the nominal returns that are often quoted.
} 
Table 1

Alternative real annual returns

\begin{tabular}{lll}
\hline & Stocks $(\%)$ & Bonds $(\%)$ \\
\hline Social Security Actuaries & 6.5 & 3.3 \\
U.S. Historical Sample, 1871-2004 & 6.8 & 2.7 \\
U.S. Historical Sample, 1950-2004 & 7.6 & 1.9 \\
U.S. Historical Sample, 1900-2000 & 7.0 & 1.5 \\
International Historical Sample, 1900-2000 & 4.8 & 1.2 \\
WSJ Economists Survey & 4.6 & 2.9
\end{tabular}

Sources: Social Security Actuaries, "Preliminary Estimated Financial Effects of a Proposal to Phase in Personal Accounts - INFORMATION," $2 / 3 / 2005$. This table reports bonds as a portfolio that is $60 \%$ corporate bonds and $40 \%$ government bonds. U.S. historical returns are geometric average returns of a portfolio that is invested $50 \%$ in long-term bonds and $50 \%$ in 1-year commercial paper or certificates of deposit. These data are described in Shiller (2005b), Irrational Exuberance and available at www.irrationalexuberance.com. The international sample is the median across 15 countries (including the U.S.) of the historical geometric average real returns as compiled by Dimson et al. (2002), Triumph of the Optimists. WSJ Survey is median expectations for next 44 years of 10 economists surveyed, published on 2/28/05, in a portfolio that is $60 \%$ corporate bonds and $40 \%$ government bonds.

themselves forecast a considerable slowdown in GDP growth in the 21 st century compared to the experience of the 20th century.

Table 1 also shows the median of the geometric average return for 15 countries, including the United States, for 1900-2000 as reported in Dimson, Marsh and Staunton (2002). Note that the stock return is considerably lower for this international historical sample than it is for the United States alone, $4.8 \%$ rather than $7.0 \%$ over the same sample. Moreover, bond returns are also lower for the international sample, $1.2 \%$ rather than $1.5 \% .^{6}$

Brown, Goetzmann and Jorion (1999) did a study of the capital appreciation in the long history of the stock markets of 39 countries, going back as far as the 1920s. They found that while for their sample the U.S. annual real stock market capital appreciation was about $5 \%$ a year, the median for the 39 countries was only about $1.5 \%$ a year. Their results suggest an even bigger difference between the U.S. and the rest of the world. Indeed, Dimson et al. excluded many countries with poor stock market performance, such as many in Latin America, where they could not get data on returns. But I did not include the Brown et al. results in the table since their data referred to capital appreciation only, omitting the dividend component of returns.

A February 28, 2005 Wall Street Journal article by Mark Whitehouse reported the expectations for future stocks and corporate and government bonds for the next 44 years. While he does not describe how he chose his respondents, most of these respondents are prominent economists at top Wall Street firms. The median expected return on the stock market is $4.6 \%$, very close to the historical experience for the international sample, much lower than the $6.5 \%$ assumed by the Social Security Actuaries.

As a result, these simulations use two sets of data on returns: both the actual historical data and an alternative series in which the returns on stocks are lowered by 2.2 percentage point per

\footnotetext{
${ }^{6}$ Dimson et al. themselves report the geometric average real return 1900-2000 of 5.8\% per year for stocks for a world portfolio comprised of the individual countries, where portfolio weights for the countries are proportional to their GDPs. This figure is higher than the median shown in the table because it is a weighted average of returns that gives a great deal of weight to the United States. For an investor who diversified around the world 1900-2000, their world return is likely to be a better indicator of portfolio return than is the median. However, if we interpret each country's data as providing a separate draw of country experience unrelated to size of country, the median is likely to be a better indicator of likely future experience of a country.
} 
year, the difference seen in Table 1 between the U.S. data and the rest of the world data in Dimson et al. (2002). This adjusted returns series correspond more closely to projections of financial economists and should be emphasized more as the appropriate evaluation of the accounts going forward. $^{7}$

The Social Security actuaries have asserted that the costs to investing the funds and running the accounts will be 30 basis points per year. Accepting this estimate, the analysis below subtracts 30 basis points from returns of the accounts.

\subsection{Defining life-cycle funds}

No one knows exactly what the life-cycle funds will look like. Indeed, the asset allocation for such a fund is going to be a contentious issue; economic practitioners and theorists will have plenty to confront. The White House has been describing the fund as one that is initially concentrated in stocks, but that gradually moves towards bonds. ${ }^{8}$

Ideally, the design of life-cycle funds would reflect the risks in labor income over the life cycle and the level of income in retirement, including traditional Social Security defined benefits. ${ }^{9}$ Moreover, the funds must reflect as well the other assets, such as the home and claims on future Social Security benefits, owned by the beneficiary. In his classic Econometrica mathematical treatise on optimal investment strategies, Merton (1973) stressed that portfolio allocation must be designed to hedge future changes in investment opportunities, and Campbell and Viceira (2002) in a treatise on lifetime portfolio allocation showed that variations in future investment opportunities are of some practical significance for portfolio design.

Among those who have worked on the theory of life-cycle portfolio allocation, it is not unanimous that younger people would go more heavily into stocks. Viceira (2001) showed that high indiosyncratic labor income risk and positive correlation between stock returns and labor income can mean that the stockholdings of the young should be lower than those of retired investors. His calculations also show that the optimal portfolio can depend a lot on assumptions that are made about preferences and stochastic properties of variables, and under some assumptions the optimal portfolio may look quite extreme. One of his candidates for optimal portfolios has young people investing over $300 \%$ of their money in the stock market, borrowing on heavily on margin far beyond the limits imposed by margin requirements today.

\footnotetext{
${ }^{7}$ Note, if the life-cycle equity account is assumed to invest in international equities, as recommended by most financial advisers and included as an option in the TSP, then including international returns would be appropriate even in a purely historical simulation without any adjustment. Realistically, however, there is a "home bias" in most investors' portfolios, and most of the portfolio is likely to remain in the U.S. In the Thrift Savings Plan that is the model for the personal accounts, participants chose to invest only $1.8 \%$ of account balances in the I Fund (international) as of December 31 , 2003.

8 A problem with this general notion, as Siegel (2002) pointed out in his book Stocks for the Long Run, is that over a really long-term sample 1802-2000 for long-term investors, in real terms investments in bonds have actually been riskier than investments in stocks. This is because over long intervals of time changes in the consumer price index (CPI) have cumulated to cause major changes in the real value of long-term bonds, whose values are fixed in nominal terms. However, over more recent samples, such as 1871-2004, stocks have been clearly more risky in real terms than bonds for long-horizon investors.

${ }^{9}$ Paul Samuelson showed in 1966 under fairly general assumptions that in the absence of non-portfolio sources of income, young and old investors would both have the same risk tolerance in their portfolios. Bodie, Merton and Samuelson (1992) and Heaton and Lucas (1997) showed that if labor income is added to the model, employed persons will optimally hold more risky assets than will retired persons. These issues are summarized in Shiller (2005b).
} 
Benzoni et al. (in press) showed that if one takes account not only of the contemporaneous correlation between stock returns and labor income, but also the correlation through time, then it may be that young people should not only own a lower fraction of their income in stocks than older people, but beyond that, they should actually be short the stock market. Andrew Lynch and Sinan Tan concluded that young people should have a lower proportion of stocks in their portfolios than old people, given that when stock returns are low (as in a recession) there is both lower mean income growth and higher volatility. We learn from these studies that there are a lot of difficult issues to confront in designing the optimal life-cycle portfolio, and that there is an extraordinarily wide range of possibilities, not just the possibilities that might sound intuitively plausible at first glance.

These papers all neglected to consider the difference between domestic and foreign stocks. Baxter and Jermann (1997) showed evidence that it is optimal for individuals to short their own country's stock market and go long the stock market for foreign countries. The possibility that the optimal life cycle portfolio would favor foreign stocks so strongly at the expense of domestic stocks has not yet been investigated. However, it is probably doubtful that governments would at this time of history institute a life-cycle portfolio that would the short own-country stock market.

Obviously, the design of a life-cycle fund for Social Security is not a simple matter. It is difficult to predict now how the concept of life-cycle funds will be interpreted in coming decades.

The most likely model for the life-cycle plan that is instituted, at least initially, would be based on existing life-cycle plans. Unfortunately, life-cycle plans that are currently privately offered vary considerably. Furthermore, these life-cycle plans are designed for people to save in addition to Social Security and by reducing current consumption. In contrast, the life-cycle accounts in Bush's plan would be for people who would expect a substantially smaller traditional Social Security benefit. Specifically, in a system reformed to be permanently sustainable, Bush's accounts might lead to a traditional Social Security benefit of about $\$ 5000$ or even less for a middle-income worker. As we shall see below, the optimal portfolio for people who are offered a new option to buy stocks on margin would be to invest entirely in risk-free Treasury bonds. A reasonable lifecycle portfolio would fall somewhere between these two extremes of current life-cycle portfolios and investing entirely in bonds.

The Vanguard Target Retirement 2045 Fund is for people expecting to retire around 2045. As of September 30, 2004, this fund had Vanguard Total Stock Market Index Fund 71.2\%, Vanguard European Stock Index Fund 12.4\%, Vanguard Total Bond Market Index Fund 11.0\%, and Vanguard Pacific Stock Index Fund 5.4\%. The prospectus says that the allocations will gradually be changed towards those of the Vanguard Target Retirement Income Fund (which is aimed at current retirees): Vanguard Total Bond Market Index Fund 50.0\%, Vanguard Inflation-Protected Securities Fund 25.0\%, Vanguard Stock Market Index Fund 20.0\%, and Vanguard Money Market Fund $5.0 \%$.

T. Rowe Price Retirement 2040 Fund starts out, according to its prospectus, investing $90 \%$ in stocks, $10 \%$ in fixed income, and $0 \%$ in conservative fixed income. It will convert into the Retirement Income Fund approximately 5 years after reaching their target dates. Thus, it would eventually be $40 \%$ stocks, $30 \%$ fixed income, and $30 \%$ conservative fixed income.

These funds, which must pass the market test to the general public in its current mindset, may not represent the funds that will be designed for the personal accounts. They may under-represent the money market, since money market returns have recently been very low and apparently unattractive to investors to whom these funds must make a sales pitch, even if money market rates will be much higher in future years when the fund shifts into them. Today's funds may under-represent inflation-protection securities because the general public has been very cool to 
these, but it would be rational if inflation protection securities became a significant portion of the asset allocation of life-cycle funds as year pass, and this may thus be expected to happen.

For the purposes of this historical simulation, for which historical data must be found, I have assumed that the allocation for the life-cycle accounts will be between two funds, a U.S. equity fund (analogous to the C Fund in the Thrift Savings Plan that is offered to U.S. government employees) and a bond-money-market fund that is 50\% long-term U.S. government bonds and $50 \%$ private-sector money market (6-month commercial paper until 1997, 6-month certificates of deposit thereafter). I am assuming that the G Fund offered by the Thrift Savings Plan will not be available for the personal accounts, and under that assumption it would be reasonable to suppose that a bond fund would combine both public long term and private short term debt. ${ }^{10}$

I consider six potential asset allocations:

- Baseline life-cycle portfolio: This portfolio is invested $85 \%$ in equities through age 29 and then gradually falls to $15 \%$ in equities by age 60 . This is slightly more conservative than the Vanguard portfolio, reflecting the fact that this portfolio is designed to largely replace the existing Social Security benefit.

- Entirely bonds portfolio: This portfolio is invested $100 \%$ in bonds, specifically $50 \%$ in long-term bonds and $50 \%$ in money market. This portfolio itself is not risk free.

- Conservative life-cycle portfolio: This portfolio follows the same pattern as the baseline lifecycle portfolio, but falls from $70 \%$ in equities to $10 \%$ in equities.

- 50\% stock portfolio: This portfolio is fixed at 50\% in equities; it does not vary with the lifecycle. This corresponds to the featured portfolio in the President's Commission to Strengthen Social Security, which the Social Security actuaries projected would have a real rate of return of $4.6 \%$. $^{11}$

- Aggressive life-cycle portfolio: This portfolio follows the same pattern as the baseline life-cycle portfolio, but falls from $90 \%$ in equities to $40 \%$ in equities.

- Entirely stocks portfolio: This portfolio is invested $100 \%$ in equities in every period.

\section{Simulation results}

Results are shown in Tables 2 and 3. Two benchmarks are used to assess each portfolio. First, the tables show the internal rate of return for the stream of payments represented by the contributions. An internal rate of return in excess of $3 \%$ means that the personal account exceeded the offset and the worker is better off. Second, the tables present the final net value of choosing the personal account after the benefit offset. The tables show various summary measures for these benchmarks for the five portfolios.

The baseline case shown in the tables assumes that stocks return $6.5 \%$ each year and that bonds earn $3.3 \%$ each year, the assumption of the Social Security actuaries (assuming "bonds" are a composite of government bonds and corporate bonds). This means that the stocks earn $6.2 \%$ a

\footnotetext{
10 The G Fund invests in short-term government securities specially created for it, not available to the general investing public. These securities pay the long-term interest rate as if it were a short rate. Since long-term bonds generally have a higher yield than short-term bonds, these securities tend to outperform short-term securities with no additional risk. The G Fund is effectively subsidized by the Federal Government; it may be unlikely that the government will offer such a subsidy to the general public.

11 President's Commission to Strengthen Social Security, Strengthening Social Security and Creating Personal Wealth for All Americans, 2001.
} 
Table 2

Results of simulations with U.S. historical data

\begin{tabular}{|c|c|c|c|c|c|c|c|c|c|c|c|c|}
\hline & \multicolumn{2}{|c|}{ Baseline life-cycle } & \multicolumn{2}{|l|}{ All bonds } & \multicolumn{2}{|c|}{ Conservative life-cycle } & \multicolumn{2}{|c|}{$\begin{array}{l}\text { 50-50 Portfolio } \\
\text { (Commission Plans) }\end{array}$} & \multicolumn{2}{|c|}{ Aggressive life-cycle } & \multicolumn{2}{|l|}{ All stocks } \\
\hline & $(1)^{\mathrm{a}}$ & $(2)^{\mathrm{a}}$ & $(3)^{\mathrm{a}}$ & $(4)^{\mathrm{a}}$ & $(5)^{\mathrm{a}}$ & $(6)^{\mathrm{a}}$ & $(7)^{\mathrm{a}}$ & $(8)^{\mathrm{a}}$ & $(9)^{\mathrm{a}}$ & $(10)^{\mathrm{a}}$ & $(11)^{\mathrm{a}}$ & $(12)^{\mathrm{a}}$ \\
\hline Initial equity share (\%) & 85 & & 0 & & 70 & & 50 & & 90 & & 100 & \\
\hline Final equity share (\%) & 15 & & 0 & & 10 & & 50 & & 40 & & 100 & \\
\hline Actuaries baseline & $\$ 52,756$ & $4.3 \%$ & $\$ 0$ & $3.0 \%$ & $\$ 39,475$ & $4.0 \%$ & $\$ 69,562$ & $4.6 \%$ & $\$ 83,852$ & $4.9 \%$ & $\$ 178,589$ & $6.2 \%$ \\
\hline Losing simulations & 29 & & 81 & & 51 & & 18 & & 7 & & 2 & \\
\hline Total simulations & 91 & & 91 & & 91 & & 91 & & 91 & & 91 & \\
\hline$\%$ Lose & 32 & & 89 & & 56 & & 20 & & 8 & & 2 & \\
\hline \multirow[t]{2}{*}{$\%$ IRR $<2 \%$} & 2 & & 68 & & 13 & & 4 & & 1 & & 0 & \\
\hline & Net value (\$) & $\operatorname{IRR}(\%)$ & Net value (\$) & $\operatorname{IRR}(\%)$ & Net value (\$) & $\operatorname{IRR}(\%)$ & Net value (\$) & $\operatorname{IRR}(\%)$ & Net value (\$) & $\operatorname{IRR}(\%)$ & Net value (\$) & $\operatorname{IRR}(\%)$ \\
\hline Median & 15,172 & 3.4 & $-50,997$ & 1.1 & $-9,564$ & 2.7 & 47,435 & 4.2 & 67,335 & 4.6 & 157,708 & 5.9 \\
\hline Mean & 17,634 & 3.4 & $-44,932$ & 1.2 & 921 & 2.9 & 47,861 & 4.0 & 62,317 & 4.4 & 206,566 & 6.1 \\
\hline Min & $-43,197$ & 1.5 & $-87,042$ & -1.1 & $-49,642$ & 1.2 & $-42,709$ & 1.6 & $-35,147$ & 1.9 & $-24,960$ & 2.3 \\
\hline 10th pet & $-20,569$ & 2.4 & $-75,796$ & -0.3 & $-34,108$ & 1.9 & $-19,994$ & 2.4 & 7,330 & 3.2 & 42,226 & 4.1 \\
\hline 25th pct & $-5,112$ & 2.9 & $-72,413$ & -0.1 & $-22,396$ & 2.3 & 13,244 & 3.4 & 29,561 & 3.8 & 91,797 & 5.0 \\
\hline 75th pet & 40,460 & 4.4 & $-15,552$ & 2.8 & 23,395 & 4.1 & 86,572 & 5.0 & 93,616 & 5.2 & 318,653 & 8.3 \\
\hline 90th pet & 62,814 & 4.5 & 322 & 3.0 & 47,960 & 4.2 & 101,450 & 5.2 & 111,593 & 5.3 & 474,990 & 8.6 \\
\hline Max & 74,355 & 4.7 & 10,671 & 3.3 & 54,406 & 4.3 & 157,821 & 5.9 & 145,294 & 5.8 & 580,685 & 9.2 \\
\hline
\end{tabular}

Note: Initial equity allocation is through age 29; final equity allocation is starting at age 60 .

a Column number. 
Table 3

Results of simulations with U.S. historical data adjusted for historical world median

\begin{tabular}{|c|c|c|c|c|c|c|c|c|c|c|c|c|}
\hline & \multicolumn{2}{|c|}{ Baseline Life-cycle } & \multicolumn{2}{|l|}{ All Bonds } & \multicolumn{2}{|c|}{ Conservative Life-cycle } & \multicolumn{2}{|c|}{$\begin{array}{l}\text { 50-50 Portfolio } \\
\text { (Commission Plans) }\end{array}$} & \multicolumn{2}{|c|}{ Aggressive Life-cycle } & \multicolumn{2}{|l|}{ All Stocks } \\
\hline & $(1)^{\mathrm{a}}$ & $(2)^{\mathrm{a}}$ & $(3)^{\mathrm{a}}$ & $(4)^{\mathrm{a}}$ & $(5)^{\mathrm{a}}$ & $(6)^{\mathrm{a}}$ & $(7)^{\mathrm{a}}$ & $(8)^{\mathrm{a}}$ & $(9)^{\mathrm{a}}$ & $(10)^{\mathrm{a}}$ & $(11)^{\mathrm{a}}$ & $(12)^{\mathrm{a}}$ \\
\hline Initial equity share (\%) & 85 & & 0 & & 70 & & 50 & & 90 & & 100 & \\
\hline Final equity share (\%) & 15 & & 0 & & 10 & & 50 & & 40 & & 100 & \\
\hline Actuaries baseline & $\$ 52,756$ & $4.3 \%$ & $\$ 0$ & $3.0 \%$ & $\$ 39,475$ & $4.0 \%$ & $\$ 69,562$ & $4.6 \%$ & $\$ 83,852$ & $4.9 \%$ & $\$ 178,589$ & $6.2 \%$ \\
\hline Losing simulations & 65 & & 81 & & 69 & & 43 & & 35 & & 30 & \\
\hline Total simulations & 91 & & 91 & & 91 & & 91 & & 91 & & 91 & \\
\hline$\%$ Lose & 71 & & 89 & & 76 & & 47 & & 38 & & 33 & \\
\hline \multirow[t]{2}{*}{$\%$ IRR $<2 \%$} & 30 & & 68 & & 46 & & 23 & & 14 & & 12 & \\
\hline & Net value (\$) & IRR (\%) & Net value (\$) & $\operatorname{IRR}(\%)$ & Net value (\$) & $\operatorname{IRR}(\%)$ & Net value (\$) & $\operatorname{IRR}(\%)$ & Net value (\$) & $\operatorname{IRR}(\%)$ & Net value (\$) & $\operatorname{IRR}(\%)$ \\
\hline Median & $-14,593$ & 2.6 & $-50,997$ & 1.1 & $-29,212$ & 2.1 & 2,578 & 3.1 & 10,374 & 3.3 & 27,947 & 3.7 \\
\hline Mean & $-13,205$ & 2.5 & $-44,932$ & 1.2 & $-20,755$ & 2.2 & 3,046 & 2.9 & 6,665 & 3.1 & 56,908 & 3.9 \\
\hline Min & $-64,572$ & 0.5 & $-87,042$ & -1.1 & $-65,663$ & 0.4 & $-68,745$ & 0.2 & $-66,746$ & 0.3 & $-79,414$ & -0.5 \\
\hline 10th pct & $-44,761$ & 1.4 & $-75,796$ & -0.3 & $-51,188$ & 1.1 & $-49,980$ & 1.2 & $-35,367$ & 1.8 & $-37,218$ & 1.7 \\
\hline 25 th pct & $-33,213$ & 1.9 & $-72,413$ & -0.1 & $-41,232$ & 1.6 & $-23,970$ & 2.2 & $-19,640$ & 2.4 & $-12,917$ & 2.6 \\
\hline 75th pct & 5,651 & 3.6 & $-15,552$ & 2.8 & $-1,412$ & 3.4 & 31,054 & 4.0 & 29,272 & 3.9 & 125,471 & 6.4 \\
\hline 90th pct & 26,124 & 3.7 & 322 & 3.0 & 20,472 & 3.5 & 43,030 & 4.1 & 42,616 & 4.1 & 208,396 & 6.5 \\
\hline $\operatorname{Max}$ & 35,627 & 3.9 & 10,671 & 3.3 & 26,721 & 3.7 & 92,489 & 5.0 & 74,720 & 4.7 & 270,527 & 7.1 \\
\hline
\end{tabular}

${ }^{\text {a }}$ Column number. 


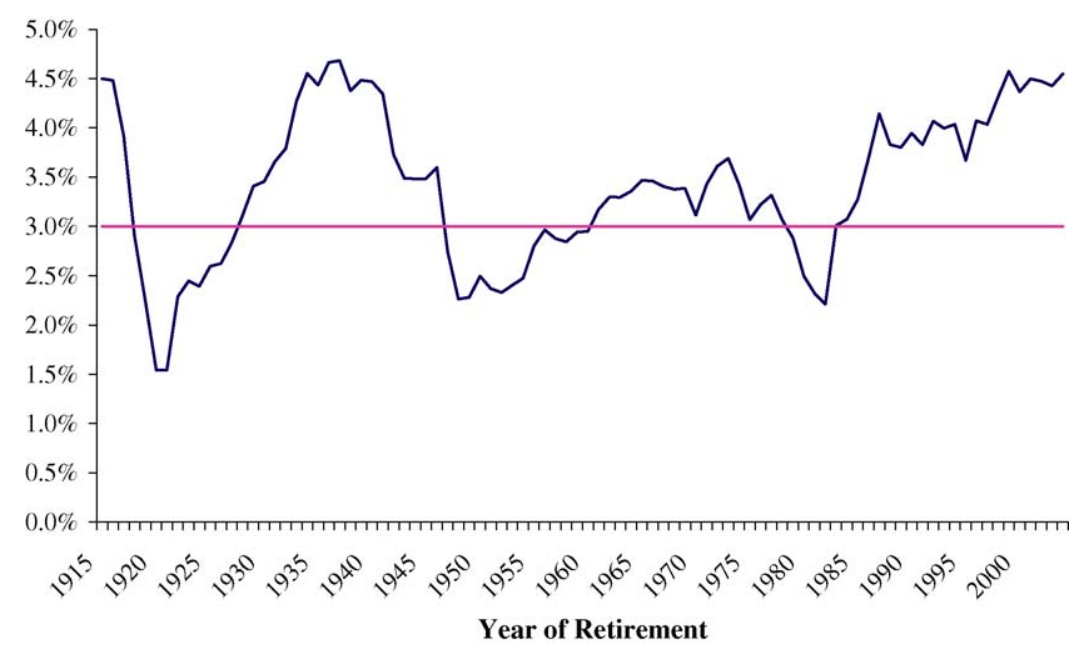

Fig. 1. Simulated internal rate of return for U.S. historical returns.

year and bonds earn 3.0\% a year after expenses. Note that from the tables that the baseline case for a portfolio $100 \%$ in bonds (column 4) ends up with a zero balance, even though the account is associated with some risk because it is partially invested in corporate bonds.

Table 2 shows results using U.S. historical data. In Table 3, the returns on stocks are lowered by $2.2 \%$ a year, the difference seen in Table 1 between the U.S. data and the rest of the world data in Dimson et al. (2002). Figs. 1 and 2 show the internal rates of return for the baseline life-cycle portfolio by the year of retirement.

When historical U.S. returns are used for the analysis, the baseline life-cycle portfolio (Table 2, columns 1 and 2) is at best disappointing, at least compared with the rhetoric that has characterized much of the advocacy for the personal accounts. The real internal rate of return is only $3.4 \%$ a year, only slightly above the offset rate of $3 \%$. While the median final portfolio value (after offset)

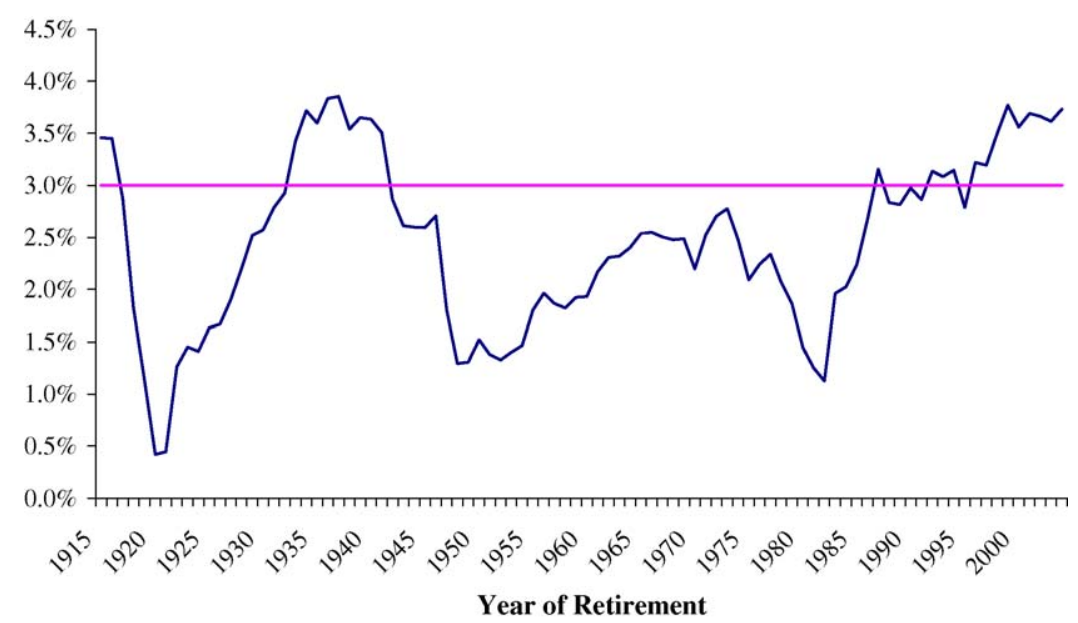

Fig. 2. Simulated internal rate of return for U.S. historical returns adjusted for historical medians. 
is positive, the portfolio value is rather small, only $\$ 15,172$ (net of the reduction in the traditional benefit). The portfolio value after offset is hardly a windfall. The lifetime annuity value of $\$ 15,172$ is about $\$ 1,000$ a year. Compare this with the benefits for our "scaled medium earner." Those benefits are promised to be $\$ 21,770$ under the current schedule, are $\$ 15,934$ on the "payable" baseline (which assumes benefits are paid from payroll taxes after the trust fund is exhausted), and would be $\$ 14,025$ with price indexing. Any of these conventional Social Security benefits would dominate the median extra annuity income created by the personal account. Moreover, there is a substantial probability that the worker will actually lose from having participated in the program. The portfolio minus offset winds up with negative value (after offset) $32 \%$ of the time.

Workers could do better, of course, if they eschewed the life-cycle accounts and went for $100 \%$ stocks. In this case (Table 2, columns 11 and 12) indeed the performance of the personal account lives up to the kind of expectations that many recent discussions of personal accounts have suggested. The median net account upon retirement is $\$ 157,708$, ten times as large as with the baseline life-cycle account, and the internal rate of return on participating in Social Security is $5.9 \%$. Workers who choose the $100 \%$ stocks option lose only $2 \%$ of the time. The internal rate of return is a little lower than the $6.2 \%$ after expenses in the baseline case, substantially because most cohorts miss out on the spectacular returns of the 1990s. Note from the table that the 100\% stocks portfolio stochastically dominates the baseline life-cycle portfolio: at all return percentiles it does better.

Of course the outcome of a portfolio of $100 \%$ bonds (Table 2, columns 3 and 4 ) is terrible. The final balance is negative $89 \%$ of the time. This is no surprise given that bonds have performed historically less well than the $3 \%$ offset rate.

Given that a $100 \%$ stock portfolio does not disappoint, one might be inclined to think that an aggressive life-cycle portfolio would do similarly well. The aggressive life-cycle portfolio (Table 2, columns 7 and 8) does less well assuming historical returns than a portfolio that is 100\% stocks, but still ends up with a median net account of $\$ 67,335$. When compared with the $100 \%$ stock portfolio, the aggressive portfolio sacrifices a great deal of upside potential for only modest declines in the downside risk. There is some concern that the balance winds up negative $8 \%$ of the time.

The conservative life-cycle portfolio (Table 2, columns 5 and 6) does much less well assuming historical returns than does the aggressive life-cycle portfolio: the median net account is a negative $\$ 9564$, and the account winds up negative $56 \%$ of the time. The $50-50$ portfolio considered by the President's Commission is somewhere between these two life-cycle portfolios, losing money $20 \%$ of the time.

When we look at the more realistic case, returns adjusted for international average returns, Table 3, all the portfolios involving stocks do less well. Notably, the baseline life-cycle portfolio (Table 3, columns 1 and 2) now has a negative median value upon retirement, and is negative $71 \%$ of the time. For this baseline portfolio, there is a $25 \%$ chance that the value upon retirement is less than a negative $\$ 33,213$, which would mean, assuming the payable baseline for conventional benefits, that benefits would fall from about $\$ 16,000$ a year for those who did not participate in the personal accounts to $\$ 14,000$ a year for those who did, after the annuitized offset is subtracted.

Here, with the adjusted returns, the $100 \%$ stocks portfolio (Table 3, columns 11 and 12) does only a little better than the baseline life-cycle portfolio that was shown in Table 2: the median net account is $\$ 27,947$, and the account is negative $33 \%$ of the time. With the adjusted returns, the $100 \%$ stocks portfolio no longer stochastically dominates the baseline life-cycle portfolio.

As one might infer from the weak performance of the $100 \%$ stock portfolio, the life-cycle funds do really badly. For the aggressive life-cycle fund (Table 3, columns 9 and 10), the median 
net account is only $\$ 10,374$, and the account is negative $38 \%$ of the time. For the conservative life-cycle fund (Table 3, columns 5 and 6) the median account is a negative $\$ 29,212$, and the net account is negative $76 \%$ of the time.

Why is the overall advantage to these life-cycle portfolios so low? Much public discussion has implied that, with the historical experience, we should expect great returns from such an account.

The most important reason for the disappointing performance of the life-cycle portfolio is just that the returns of the safer assets are below the $3 \%$ real rate used to compute the offset. The returns on the stock market are not high enough to make the life-cycle portfolio a good investment, especially if we use the stock returns computed from the experience of the world, as shown in Table 3.

Moreover, with these life-cycle portfolios, relatively little is contributed when the allocation to stocks is high, since earnings are relatively low in the younger years. Workers contribute only a little to stocks, and do not enjoy a strong effect of compounding, since the proceeds of the early investments are taken out of the stock market as time goes on.

Ultimately, there is no getting around the fact that stocks are risky investments, that the higher average return on stocks is at least in part a compensation for such risk.

\section{Which portfolio should workers choose?}

The results are disappointing for the life-cycle portfolios, especially when we use the more realistic assumption about future returns that they should match world experience rather than the experience of the U.S. One is tempted to say that workers should eschew the life-cycle portfolio altogether, and participate only in the $100 \%$ stocks portfolio.

That would appear to be the correct conclusion for many workers. For example, consider a worker who finds it difficult to invest in the stock market because of purely psychological inhibitions, who is excessively fearful about the market, and who invests only in an account at the local savings and loan association. Given the reassurance from the government that Bush's plan is a good one, and given the high-predicted returns for the $100 \%$ stocks portfolio, that worker might just be tipped into electing the personal accounts and investing in the $100 \%$ stock market portfolio. If that worker also continues to save a lot in the savings and loan association, the worker's overall portfolio with the personal account $100 \%$ in stocks might represent a distinct improvement in the overall portfolio, even if it is not a life-cycle portfolio. Advisors might well not mention the life-cycle portfolio for this worker, not only because it doesn't look attractive enough that the worker would really follow up and elect a personal account, but also because, when combined with the worker's large savings and loan account, the worker's overall portfolio may not have enough exposure to stocks.

For workers who have a different sort of psychological barrier, who are unable to save, the advice would be different. These workers will be totally dependent on the Social Security system for their survival. As was noted above, the offset has the effect of drastically reducing the guaranteed conventional Social Security benefit. With any of the life-cycle accounts, and also with the $100 \%$ Social Security accounts, there is a significant chance of loss that will be painful to bear in retirement. For these workers, given their psychological problems, it would appear that the best advice is not to participate at all in the personal accounts.

If we are considering workers who are not inhibited by psychological barriers, workers who will follow the optimal strategy, then the advice we would give would look very different. There are two issues in considering the optimal portfolio in Bush's plan: first, is it rational to participate in the accounts? Second, conditional on participating in the accounts, what is the optimal portfolio? 
For such workers, who already have optimized their portfolios before being offered the personal accounts, it is not generally rational to participate in the personal accounts at all. Such a worker will already be diversified and will already own both stocks and bonds. We have noted that participating in the personal account amounts to borrowing at a 3\% real rate to buy a portfolio of stocks and/or bonds. But, this worker can already in effect borrow at a rate lower than 3\%: just sell some of the bonds already owned (which have an expected real yield less than $3 \%$ ) to get the money to make the desired adjustments in the portfolio. For example, a worker who wished to make his portfolio riskier by investing more in stocks could just sell some of his or her bonds and buy more stocks. ${ }^{12}$

We have seen that the safest assets available have a historical real return that is less than $3 \%$. Currently, Treasury inflation-indexed bonds have average yields that are below $2 \%$. As a result, borrowing at $3 \%$ to invest in an asset that is yielding less than $3 \%$ would entail serious costs. ${ }^{13}$

But, can we advise such an optimizing worker who has already decided to invest in a personal account what account to choose? Suppose that worker is somehow compelled to choose the personal accounts. The worker already holds an optimally diversified portfolio of stocks and bonds so that, on the margin, the average equity premium was just enough to compensate risk associated with stocks. Conditional on participating in the accounts, the rational choice would be to invest the entire portfolio in bonds. That way the risk and return of the overall portfolio would stay essentially unchanged. The personal account portfolio would be used merely to cancel out the debt represented by the offset. ${ }^{14}$

The optimizing investor would be made worse off if he or she used the personal account to acquire more equities because he or she is already just at the point where the additional risks associated with equities outweigh the higher returns associated with equities.

\section{Interpretation of results and lessons for the design of Social Security}

In this paper, I have concentrated mostly on analyzing the Bush proposal for life-cycle accounts, and not tried to compute the optimal life-cycle portfolios for people in relation to the particular

\footnotetext{
12 There may be a reason for some of these workers to participate in the personal accounts as a way to lower their federal income taxes, however any such tax-avoidance motivations for participating in personal accounts are complex to analyze, and depend not only on current tax law but also on tax laws decades into the future. Under present tax law, workers desiring to increase their exposure to the stock market because of anticipated high returns on stocks would do better to sell some bonds and put the proceeds in a Roth IRA, which is not subject to taxation at the end as Social Security benefits often are.

If the individual held no bonds at all and wished to go even more heavily into stocks, he or she could make use of margin lending facilities currently available to the public from brokerage firms, bypassing the personal accounts. Here, however, the real margin rate is unlikely to be as low as $3 \%$ except for large accounts.

13 Some rational constrained investors might choose to participate. For example, someone who is invested $100 \%$ in stocks, has such high return expectations for stocks that $100 \%$ appears too low, and does not have alternative borrowing opportunities at less than a $3 \%$ real rate, would choose to participate.

${ }^{14}$ Technically, the individual could not perfectly offset the effects of participating in the personal accounts, since the real borrowing rate of $3 \%$ does not exactly match, and is likely to exceed, the return obtainable by investing in bonds. Still, if compelled to participate, the best thing to do, to a first approximation from a risk-management perspective, would be to swallow the loss and invest in bonds. Note that the worker could also choose to invest the personal account $100 \%$ in stocks and at the same time sell stocks in his or her brokerage account, substituting bonds for stocks in the brokerage account so that the overall portfolio, brokerage account and personal account together, remain unchanged. Which assets are in the personal account and which in the brokerage account will not matter, except for possible tax effects.
} 
barriers that they have to investing properly. The political reality is that governments are not likely to implement any time soon a complex array of life-cycle portfolios, each intended for a certain group of people, nor are they likely to design the optimal portfolios that have been described by some authors, such as life-cycle portfolios that are 300\% stocks for young investors, or that are short the domestic stock market and long the rest of the world's stock markets. Policy modeling to be relevant has to analyze the politically feasible proposals, as well as the arguments that are made for them. The dominant argument for the Bush proposal has been simply that it will capture the historically high returns on the stock market and keep risks well under control. We have seen that, as represented by the simulations presented in Tables 2 and 3, there is a disappointing outlook for investors relative to the rhetoric of their promoters.

I think that the disappointment may be even greater than the tables indicate. The simulations depended on the historical experience of either the United States or the rest of the world for over a century. While a century may seem like a long enough sample period to prove any point, in fact even with a century of data we do not know the true probability distribution of future returns. The 21 st century may differ fundamentally from the 20th. Moreover, whenever we look at long historical data on stock markets, we are of course looking at survivors, stock markets that made it, and ignoring countries where conditions turned out so badly that we get little or no stock market data. ${ }^{15}$ Obviously, Russia and China were not in Dimson et al. for their century-long data set. While it is highly unlikely that the particular upheavals that hit Russia and China in the 20th century will repeat themselves in the U.S. in the 21 st century, it should be remembered that nobody predicted in 1900 the kind of upheavals that were to follow in Russia or China. Similarly, it is difficult for us to imagine all the different kinds of things that might disrupt stock market performance in the future. Thus, there is additional uncertainty, uncertainty of regime change or model uncertainty or survivorship bias that should ideally be taken into account. Unfortunately, there does not seem to be any objective way of quantifying this additional uncertainty about the future.

We are living in the aftermath of the spectacular stock market boom of the 1990s, a boom that generated irrational exuberance about the outlook for the stock market. A public attitude of exaggerated expectations about the stock market is still with us, and probably accounts for a good portion of the support for personal accounts. Those who rely heavily on the past U.S. experience for their expectations for the future might find attractive a life-cycle account that is even more heavily into the stock market in the younger years, such as the aggressive life-cycle account considered here or even more aggressive than that. But we have seen that the aggressive life-cycle portfolio entails serious risks too; moreover the correlation of these risks to the labor income risks will have to be a central consideration.

In thinking about the redesign of Social Security, it is important not to focus on chasing past returns and instead focus more on the theoretical fundamentals that underlie Social Security. From this perspective, the government's offering margin credit to the general public, thereby duplicating a service that is already available from the private sector, should not be the focal point of discussions. There are some important theoretical justifications for the government's providing a Social Security system, if not margin credit.

Notably, a justification for a pay-as-you-go Social Security system is that the private sector cannot allow people to share risks across generations effectively, since children, and unborn future children, cannot make financial contracts. We could redesign the existing Social Security system

\footnotetext{
15 See Brown, Goetzmann and Ross (1995).
} 
to do a better job of managing such intergenerational risk than it does today. ${ }^{16}$ But this justification for Social Security would not appear to offer a reason for the government to get involved in margin lending.

The intergenerational-risk-sharing justification for Social Security is so strong and palpable that it is likely to trump any effort to design it along different lines. That is, a design that imposes risks rather than reduces risks will ultimately be discarded. In fact, people likely know this and will likely use this information in their choice of personal accounts. With the Bush plan, many people will probably choose the $100 \%$ stocks portfolio, thinking that it might do very well, and that if it does poorly, the government will probably change the program and bail out the losers.

In any event, the $3 \%$ real offset rate of the Bush proposal appears to be too high, and if the program is instituted, it should be done with a lower rate. If the offset rate were lowered from $3 \%$ per annum to $2 \%$, it would shift the net values of the accounts at retirement shown in Tables 2 and 3 up by $\$ 30,322$ the difference between the offset cumulated at $3 \%$ and the offset cumulated at $2 \%$, generally making the median net values positive. Better yet, the offset could be cumulated at a market rate. The offset could be calculated as the terminal value of the contributions brought to the final date using actual U.S. Treasury Inflation Protected Security (TIPS) yields of the appropriate maturity.

Reducing the offset rate would move the distribution of the returns to the right, but of course would do nothing to reduce the uncertainty of the returns that we saw in Tables 2 and 3. Even with an offset rate of $2 \%$, the baseline personal account net value at retirement as simulated with adjusted historical returns (shown in column 1 of Table 3 ) would still be negative over $25 \%$ of the time.

Note that the personal account plan does nothing directly to improve the saving rate, or to make the economy grow faster. It might possibly increase the saving rate, if the experience of being invested in the financial markets and having made choices among investment accounts stimulates people to think more favorably about investing. But, the personal accounts might also have the perverse effect of lowering saving rates if people's perception that they have money in the stock market that is going to make them rich some day discourages them from saving on their own outside Social Security. Psychologists have documented a "wishful thinking bias" that encourages people to think that their own team will win the game or their own candidate will win the election; the same tendency might encourage personal account holders towards great expectations for their account. The experience of crashing saving rates in the U.S. at the same time as the stock market boomed in the last two decades suggests that the latter outcome might be more significant.

If the personal accounts do not raise saving rates and do not make the economy grow faster, then the accounts will not increase opportunities for aggregate consumption. Any increase in consumption that is provided to some people must come one way or another from others.

The argument is sometimes made that Bush's plan cannot be a bad idea because it merely expands people's choice set and so anyone can choose not to participate. But this is not valid. Those who choose not to participate in the program are still affected by it. The program will affect them through prices in the stock market; the personal accounts program could have the effect of causing speculative demand to bid up the stock market in the short run, followed by a crash in the longer run, an outcome that would help and hurt people both in and out of the personal accounts depending on the timing of their exposure to stock market risk that they chose.

Bush's Social Security plan might be described as a plan to allow small investors to use their expected future Social Security benefits as collateral for margin loans, offering a plan at such a

\footnotetext{
16 See my book The New Financial Order: Risk in the 21st Century, 2003, Chapter 12.
} 
large scale that economies of scale reduce administrative costs, and streamlining the program so that workers do not impose costs by expecting the kind of services they get from brokers, thereby making it possible for the government to charge a lower rate for margin loans than is available in the private market today. If the government does this it will not be met with unmitigated enthusiasm from the brokerage community: providing a lower rate puts the government program in competition with private margin lenders, who do not offer such attractive margin rates to small accounts. More importantly, perhaps, if the government offers a lower rate on the offset balance then the government will be losing an opportunity to lower its long-term budget deficit. The present plan saves the government money by lending to individuals at a rate that is higher than the real rate at which the government can borrow money.

We have seen that Bush's plan might well help some people (the example given was people who have savings but, because of psychological obstacles, are too conservatively invested) but may hurt other people (the example given was people who have no savings and who might invest their personal accounts in too risky a manner.) Thus, the personal account is a blunt tool. It would seem to be a better plan if the government merely subsidized personal financial advisors, making it cheaper for people to get financial advice that is really appropriate for their own economic circumstances. Today, most people get no significant professional help with their investments. With proper financial advice people could also make use of some better choices among their personal accounts, such as choices designed to hedge their labor income or home value.

Much of the design of Social Security also depends on the need to design around human foibles, and to provide public goods that might help them out of their errors. The failure of many people to save at all for their retirement is one such foible, and ultimately our society feels a need to protect such people. More broadly, a failure of many people to embrace capitalist institutions, to learn about investing and about the benefits of ownership, may also be a factor justifying actions from a government that provides an educational that will not be provided privately because it is a public good.

One might justify government intervention to help people deal with these psychological failures, and this is indeed part of the justification of Bush's ownership society. The personal accounts may indeed help achieve this, even if they are probably not the ideal vehicle for this purpose.

But to say that there is a money machine in the stock market, that it can be tapped to yield great wealth without significant risk if one uses life-cycle investment methods, is a big mistake. The stock market is an uncertain place, and even if the risk is effectively managed over the life cycle, important uncertainty remains.

\section{Acknowledgments}

The author wishes to thank Jason Furman for substantial assistance, and to participants at seminars at the Stern School of Business, New York University the Graduate School of Business, Stanford University, the Haas School of Business, University of California, Berkeley, and the Department of Economics, Yale University, for helpful comments.

\section{References}

Baxter, M., \& Jermann, U. (1997). The international diversification puzzle is worse than you think. American Economic Review, 87, 170-180.

Benzoni, L., Collin-Dufresne, P., \& Goldstein, R. S. Portfolio choice over the life-cycle in the presence of trickle-down labor income. 
Bodie, Z., Merton, R. C., \& Samuelson, W. F. (1992). Labor supply flexibility and portfolio choice in a life-cycle model. Journal of Economic Dynamics and Control, 16, 427-449.

Brown, S. J., Goetzmann, W. N., \& Jorion, P. (1999). Global stock markets in the twentieth century. Journal of Finance, 54(3), 953-980.

Brown, S. J., Goetzmann, W. N., \& Ross, S. A. (1995). Survival. Journal of Finance, 50(3), 853-873.

Campbell, J. Y., \& Viceira, L. (2002). Strategic asset allocation: Portfolio choice for long-term investors. Oxford: Oxford University Press.

Dimson, E., Marsh, P., \& Staunton, M. (2002). Triumph of the optimists: 101 years of global investment returns. Princeton, NJ, Oxford: Princeton University Press.

Geanakoplos, J., Mitchell, O. S., \& Zeldes, S. P. (2000). Social Security Money’s Worth Cowles Foundation Discussion Paper No. 1005.

Heaton, J., \& Lucas, D. (1997). Market behavior, savings behavior, and portfolio choice. Journal of Finance, 55, 1163-1198.

Lynch, A., \& Tan, S. (2004, November). Labor income dynamics at business-cycle frequencies: Implications for portfolio choice. Unpublished paper, Stern School of Business, New York University.

Merton, R. C. (1973). An intertemporal capital asset pricing model. Econometrica, 41, 867-880.

Office of the Press Secretary. (2005a, February 2). The White House, Background Press briefing on Social Security.

Office of the Press Secretary. (2005b, February). Strengthening Social Security for the 21 st century.

President's Commission to Strengthen Social Security. (2001). Strengthening Social Security and creating personal wealth for all Americans.

Samuelson, P. A. (1969). Lifetime portfolio selection by dynamic stochastic programming. Review of Economics and Statistics, 51, 239-246. (Reprinted in Stiglitz, J. (Ed.). (1972). The collected scientific papers of Paul A. Samuelson (Vol 3, pp. 883-890). MIT Press.).

Shiller, R. J. (1989). Market volatility. Cambridge, MA: M.I.T. Press.

Shiller, R. J. (2003). The new financial order: Risk in the 21st century. Princeton, NJ: Princeton University Press.

Shiller, R. J. (2005). Irrational exuberance (2nd edn). Princeton, NJ: Princeton University Press.

Shiller, R. J. (2005c). Life-cycle portfolios as government policy. Economist's Voice, 2(1) (Article 14).

Siegel, J. (2002). Stocks for the long run (3rd edn). New York: McGraw Hill.

Viceira, L. (2001). Optimal portfolio choice for long-horizon returns with non-tradable labor income. Journal of Finance, $56,433-470$.

Whitehouse, M. (2005, February 28). Social Security overhaul plan leans on a bullish market. Wall Street Journal, p. C1 col. 2, C col. 6 .

\section{Further reading}

Shiller, R. J. (2005a). American casino: The promise and perils of Bush's 'Ownership Society'. The Atlantic, pp. 33-34. 